Article

\title{
Pharmacokinetics of Shikimic Acid Following Intragastric and Intravenous Administrations in Rats
}

\author{
Keumhan Noh ${ }^{1,+}$, Hyun-Moon Back ${ }^{2,+}$, Beom Soo Shin ${ }^{3, *}$ and Wonku Kang ${ }^{4, *}$ \\ 1 Deapartment of Pharmaceutical Sciences, Leslie Dan Faculty of Pharmacy, University of Toronto, \\ Toronto, ON M55 3M2, Canada; keumhan.noh@toronto.ac.ca \\ 2 Department of Pharmaceutics, Ernest Mario School of Pharmacy, Rutgers, \\ The State University of New Jersey, Piscataway, NJ 08854, USA; hyunmoon.back@rutgers.edu \\ 3 School of Pharmacy, Sungkyunkwan University, Suwon 16419, Korea \\ 4 College of Pharmacy, Chung-Ang University, Seoul 06974, Korea \\ * Correspondence: bsshin@skku.edu (B.S.S.); wkang@cau.ac.kr (W.K.); \\ Tel.: +82-10-8230-2474 (B.S.S.); +82-2-820-5601 (W.K.) \\ + The authors equally contributed to this work.
}

Received: 5 August 2020; Accepted: 25 August 2020; Published: 29 August 2020

\begin{abstract}
Shikimic acid, a critical starting material for the semi-total synthesis of oseltamivir to treat and prevent influenza, exerts many pharmacological effects. However, the optimal bioanalytical method has not been adequately defined. We used liquid chromatography-tandem mass spectrometry to quantitate shikimic acid in rat plasma and studied its pharmacokinetics after intragastric and intravenous administration. Plasma was spiked with an internal standard, and the proteins were precipitated with acetonitrile, followed by solvent evaporation and reconstitution of the mobile phase. Shikimic acid was separated on a hydrophilic reverse-phase column and showed a mass transition $\left([\mathrm{M}-\mathrm{H}]^{-}\right)$at $\mathrm{m} / \mathrm{z}$ 173.4 $\rightarrow$ 136.6. Shikimic acid exhibited bi-exponential decay after intravenous dosing, with a rapid distribution $\left(5.57 \mathrm{~h}^{-1}\right)$ up to $1 \mathrm{~h}$ followed by slow elimination $\left(0.78 \mathrm{~h}^{-1}\right)$. The steady state distribution and clearance volumes were 5.17 and $1.79 \mathrm{~L} / \mathrm{h} / \mathrm{kg}$, respectively. After intragastric administration, the shikimic acid level peaked at about $3 \mathrm{~h}$, and the material then disappeared mono-exponentially with a half-life of $1.3 \mathrm{~h}$. A double peak phenomenon was observed. The absolute oral bioavailability was about $10 \%$ in rats. We explored the relationship between the pharmacokinetics and pharmacodynamics of shikimic acid.
\end{abstract}

Keywords: shikimic acid; HPLC-MS/MS; intragastric; intravenous; pharmacokinetics

\section{Introduction}

Shikimic acid (3,4,5-trihydroxy-1-cyclohexene-1-carboxylic acid) was initially extracted from Illicium species, including I. anisatum and I. verum [1,2]. Shikimic acid is a critical starting material for semi-total synthesis of oseltamivir, which is used to treat and prevent influenza caused by the A and B viruses [1].

Shikimic acid also exhibits anti-microbial, anti-inflammatory, and analgesic actions and is a major constituent of plant stem cells [3,4]. Shikimic acid prevents nerve demyelination by promoting the differentiation of oligodendrocyte precursor cells [5] and increases the levels of cytokines that promote hair growth [6]. However, the pharmacokinetic behavior of shikimic acid has not been fully elucidated.

The absorption of shikimic acid has only been studied via in situ perfusion in rats [7], while the metabolism was explored over 40 years ago [8,9]. Adamson et al. reported that shikimic acid was converted into hippuric acid (via benzoate) after aromatization by the gut microflora of rats and monkeys [8]. However, this was disputed by Brewster et al. several years later, who showed 
that shikimate was biotransformed by the gastrointestinal microflora into cyclohexanecarboxylate, which was then aromatized and conjugated with glycine in mammalian tissues [9].

Pharmacokinetic studies require sensitive analytical methods. Shikimic acid levels in several berries [10] and spring wheat [11] have been quantified by high-performance liquid chromatography (HPLC) with ultraviolet light detection, while the levels in plant extracts were evaluated by orbitrap mass spectrometry [12], LC, and gas chromatography (GC) coupled with isotope dilution mass spectrometry (MS), or GC-MS $[13,14]$. Recently, LC-MS/MS has been used to describe the chemical constituents of Smilax glabra Roxburgh and Smilax china Linn [15]. However, no method for analyzing shikimic acid in plasma has been reported.

Therefore, we developed and validated a quantitative analytical method for determining shikimic acid levels in rat plasma via HPLC-MS/MS, assessed shikimic acid stability during the pre-treatment and storage of plasma samples, and performed a pharmacokinetic study following intragastric (ig) and intravenous (iv) administration of shikimic acid to rats.

\section{Materials and Methods}

\subsection{Materials}

Shikimic acid, diclofenac and formic acid were purchased from Sigma-Aldrich (St. Louis, MO, USA), and acetonitrile was obtained from Burdick \& Jackson (Muskegon, MI, USA). All other chemicals and solvents were of the highest analytical grade available.

\subsection{Quantification of Shikimic Acid in Plasma}

Standard solutions of shikimic acid and diclofenac (the internal standard; IS) were prepared in distilled water and methanol, respectively $(1 \mathrm{mg} / \mathrm{mL})$, and serially diluted. Then, $10 \mathrm{ng} / \mathrm{mL}$ of each solution was infused into the mass spectrometer at $10 \mu \mathrm{L} / \mathrm{min}$ and the major product ions were identified. Precursor ions and fragmentation patterns were monitored in negative ion mode. The major mass spectrometry peaks were used to quantify the compounds. The shikimic acid standard solution was serially diluted in distilled water to yield solutions of $50 \mathrm{ng} / \mathrm{mL}$ to $50 \mu \mathrm{g} / \mathrm{mL}$. Then, $10 \mu \mathrm{L}$ of each sample was added to $90 \mu \mathrm{L}$ of drug-free plasma (final concentrations of 5, 20, 50, 100, 500, 1000, and $5000 \mathrm{ng} / \mathrm{mL})$. Acetonitrile $(0.5 \mathrm{~mL})$ and $100 \mathrm{ng} / \mathrm{mL}$ diclofenac were used to spike the plasma samples. The mixtures were stirred vigorously for $10 \mathrm{~s}$ and then centrifuged at $12,000 \times g$ for $10 \mathrm{~min}$ at $4{ }^{\circ} \mathrm{C}$. Each supernatant was transferred to a tube, and the liquid was evaporated under reduced pressure at $50^{\circ} \mathrm{C}$. The residue was reconstituted with $50 \mu \mathrm{L}$ of the mobile phase. Each solution was filtered and $5 \mu \mathrm{L}$ was injected into the LC-MS/MS system. Linear regression was used to derive five calibration graphs based on the ratio of the areas under the peaks for shikimic acid and the IS.

An API 4000 LC-MS/MS system (AB SCIEX, Framingham, MA, USA) with an electrospray ionization interface was used to quantify the IS and shikimic acid. The substances were separated on a reverse-phase column (SeQuant ZIC-HILIC; $150 \times 2.1 \mathrm{~mm}$ internal diameter, $5 \mu \mathrm{m}$ particle size; Merck KGaA, Darmstadt, Germany) at $30{ }^{\circ} \mathrm{C}$. The mobile phase was a mixture of distilled water and acetonitrile (3:7 v/v with $0.1 \%$ formic acid). The elution rate was $0.2 \mathrm{~mL} / \mathrm{min}$ and was controlled by an HP 1260 series pump (Agilent, Wilmington, DE, USA); the total run time was $5 \mathrm{~min}$. The turbo ion spray interface was maintained at $4500 \mathrm{~V}$ and $450^{\circ} \mathrm{C}$. Multiple reaction monitoring (MRM) was used to quantify the precursor and its product ions, and the ratio of the peak areas for each solution was calculated. All data were processed by Analyst software (ver. 1.5.2; Applied Biosystems, Foster City, CA, USA).

\subsection{Method Validation and the Stability of Shikimic Acid}

Drug-free plasma from five rats was used to assess specificity. Shikimic acid quality controls were prepared at 4 different concentrations $(5,30,500$, and $3000 \mathrm{ng} / \mathrm{mL}$ for lower limit of quantification, low, intermediate and high concentrations, respectively). The precision and accuracy of intra- and inter-day assays were evaluated at these concentrations. Acceptable ranges were $\pm 20 \%$ for the lower limit of 
quantification and $\pm 15 \%$ for the other quality controls. Recovery was calculated by dividing the peak areas of quality controls of pre-spike by those of post-spike. A possible matrix effect was examined by dividing the peak areas of post-spike by those in neat solutions [16].

The stability of shikimic acid at concentrations of 0.1 and $1 \mu \mathrm{g} / \mathrm{mL}$ in rat plasma was examined under various conditions. The plasma samples were stored at room temperature for $4 \mathrm{~h}$ and at $-70{ }^{\circ} \mathrm{C}$ for 3 weeks to assess short- and long-term stability, respectively. Stability was assessed after three freeze-thaw cycles (from $-70{ }^{\circ} \mathrm{C}$ to room temperature) and in extracts stored for $24 \mathrm{~h}$ at $4{ }^{\circ} \mathrm{C}$. The stability values were derived by comparing the peak ratios of stored and freshly prepared samples. Variation of $\pm 15 \%$ was considered acceptable.

\subsection{Animal Study}

We used 10 male, 9-week-old Sprague Dawley rats weighing 250-260 g. The animal room was maintained at $23^{\circ} \mathrm{C}$, with a relative humidity of $50 \pm 10 \%, 10-20$ air changes/h, and a light intensity of 300 Lux under a $12 \mathrm{~h} / 12 \mathrm{~h}$ light-dark cycle. The study was approved by the Institutional Animal Care and Use Committee (IACUC) of Chung-Ang University (No. 202000054, 20, 05, 2020). All animals were cared for in accordance with the principles of the National Institutes of Health Guide for the Care and Use of Laboratory Animals. The 10 rats were randomly assigned to the ig and iv groups ( $n=5 /$ group). Shikimic acid was dissolved at $10 \mathrm{mg} / \mathrm{mL}$ in saline for ig administration $(100 \mathrm{mg} / \mathrm{kg}, 1 \mathrm{~mL} / \mathrm{kg})$ and at $2 \mathrm{mg} / \mathrm{mL}$ in saline for iv administration $(2 \mathrm{mg} / \mathrm{kg}, 1 \mathrm{~mL} / \mathrm{kg})$. To measure plasma concentrations, blood samples $(250 \mu \mathrm{L})$ were collected from the subclavian veins at 2, 5, 15, and $30 \mathrm{~min}$ and 1, 1.5, 2, 3, 4, 6, and $8 \mathrm{~h}$ after iv administration, and at $0.25,0.5,0.75,1,1.5,2,3,4,6$, and $8 \mathrm{~h}$ after ig administration. The samples were then heparinized, centrifuged at $17,000 \mathrm{rpm}$ for $10 \mathrm{~min}$, and stored at $-70{ }^{\circ} \mathrm{C}$ prior to analysis. Plasma was pre-treated as described above, and the amount of shikimic acid in the $100 \mu \mathrm{L}$ samples was determined.

\subsection{Pharmacokinetic Data Analysis}

The pharmacokinetic parameters of shikimic acid were calculated from the time courses of its plasma concentrations. The maximum concentration $\left(C_{\max }\right)$ and time to $\mathrm{C}_{\max }\left(\mathrm{T}_{\max }\right)$ were read from the individual data. The elimination rate constant $(\mathrm{k})$ was estimated by linear regression of the log-transformed plasma shikimic acid concentration in the terminal phase, and the trapezoidal rule was used to obtain the area under the plasma concentration-time curve $\left(A U C_{t}\right)$. The $A U C_{\text {inf }}$ was calculated by adding $C_{\text {last }} / k$ to $A U C_{t}$, and clearance was given as the dose $/ A U C_{i n f}$.

The apparent initial distribution rate constant $(\alpha)$ was estimated by log-linear regression of the residuals between the actual plasma concentration during distribution and the extrapolated plasma concentrations from the terminal phases, and the intercept $(\mathrm{A})$ of the curve was used to predict the initial distribution volume. The volume of distribution $\left(\mathrm{V}_{\mathrm{ss}}\right)$ in the steady state was given by the dose divided by the sum of A and the intercept (B) of the line of the log-transformed concentration in the terminal phase. All data are shown as mean and standard deviation.

\section{Results and Discussion}

\subsection{Validation of the Bioanalytical Method for Determining Shikimic Acid Levels in Rat Plasma}

Shikimic acid is hydrophilic; the water solubility is $18 \mathrm{~g} / 100 \mathrm{~mL}$ at $23{ }^{\circ} \mathrm{C}$, so the substance is freely soluble (between very soluble and soluble) in water [17]. However, shikimic acid is practically insoluble in highly lipophilic organic solvents such as petroleum ether, chloroform, and benzene. Therefore, we initially ruled out the use of a liquid-liquid extraction method for purification of the substance from plasma. Instead, we tested solid-phase extraction using an anion exchange column, but the recovery rate was very low. We tested a simple precipitation procedure using a mixture of methanol and $10 \% \mathrm{ZnSO} 4$ aqueous solution $(4: 1, v / v)$ [18], trichloroacetic acid (5\% w/v) [19], methanol, and acetonitrile separately [20-22], but the sensitivity was poor. Therefore, the organic layer was 
evaporated after protein precipitation with five volumes of acetonitrile, and the plasma samples were finally concentrated twofold.

Figure 1 shows the chemical structure of shikimic acid and its product ion mass spectrum. The precursor ion of shikimic acid in negative mode was superior to that in positive mode. Deprotonated shikimic acid ([M-H $]^{-}$at $m / z$ 173.4) was fragmented into its largest product ion at $m / z 136.6$, with a collision energy of $-16 \mathrm{eV}$. The transition from the IS precursor to the $[\mathrm{M}-\mathrm{H}]^{-}$product ion occurred at $296.1 \rightarrow 251.7$ (collision energy $-18 \mathrm{eV}$ ), as reported previously [20-22].

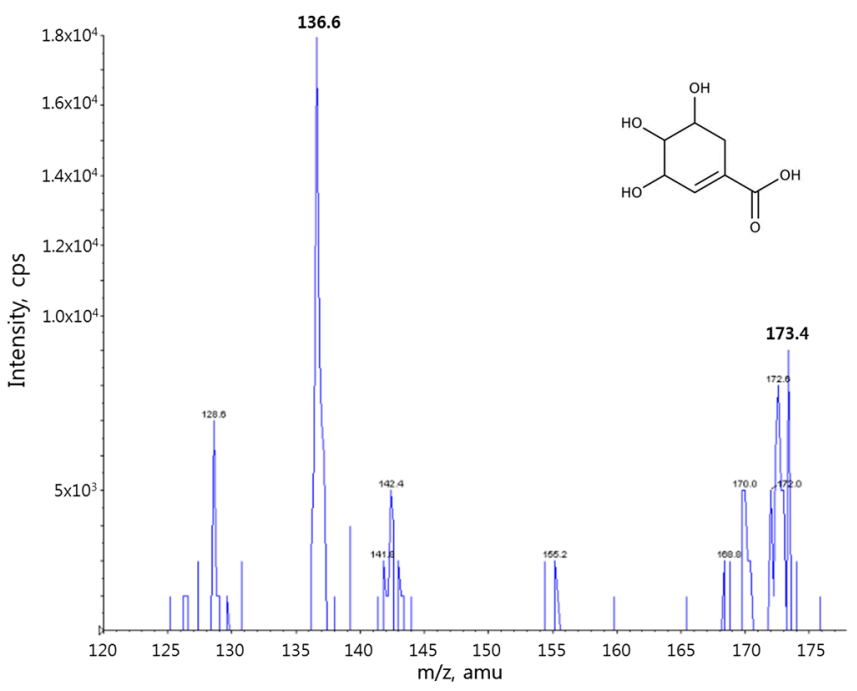

Figure 1. Chemical structure and fragment mass spectrum of shikimic acid.

An isotope of the analyte would be an ideal IS. ${ }^{14} \mathrm{C}$ - or ${ }^{13} \mathrm{C}$-labeled shikimic acid was used in a few previous studies $[9,13]$. However, no isotope of shikimic acid is currently commercially available. Although a synthetic method labeling shikimic acid with deuterium at positions $C 3$ and C4 is available [23], it is impractical, as there are many steps and a low yield. Therefore, diclofenac served as a stable IS, as in many previous reports from our laboratory [20-22].

Typical chromatograms of shikimic acid and the IS in rat plasma are shown in Figure 2. No significant endogenous interference was evident at the elution time of either substance (Figure 2A). Shikimic acid and the IS eluted at 2.63 and $1.77 \mathrm{~min}$, respectively (Figure 2B,C). On conventional reverse-phase columns (e.g., $\mathrm{C}_{18}$ and $\mathrm{C}_{8}$ ), shikimic acid eluted before $1 \mathrm{~min}$, and sensitivity was compromised by ion suppression caused by endogenous substances eluting at around the same time. Therefore, we used a hydrophilic stationary phase for retention and adequate sensitivity. Shikimic acid was more hydrophilic than the IS, and it was retained for longer by the stationary phase.

The shikimic acid-IS peak area ratios exhibited a strong linear relationship with the corresponding plasma concentrations from $5 \mathrm{ng} / \mathrm{mL}$ to $5 \mu \mathrm{g} / \mathrm{mL}\left(y=(0.149 \pm 0.030) \mathrm{x}+0.005 \pm 0.002, \mathrm{r}^{2}>0.998\right)$. The detection limit was $2 \mathrm{ng} / \mathrm{mL}$ at a signal-to-noise ratio of 3 . The intra- and inter-day assay accuracy and precision were within acceptable ranges (Table 1).

Table 1. Assay validation of shikimic acid in rat plasma.

\begin{tabular}{ccc}
\hline Concentration $(\mathbf{n g} / \mathbf{m L})$ & Intra-Day & Inter-Day \\
\hline 5 & $98.3 \pm 5.6^{\mathrm{a}}(5.7)^{\mathrm{b}}$ & $97.4 \pm 6.8(7.0)$ \\
30 & $102.2 \pm 4.5(4.4)$ & $98.6 \pm 7.2(7.3)$ \\
500 & $103.5 \pm 6.3(6.1)$ & $102.5 \pm 5.7(5.6)$ \\
3000 & $99.5 \pm 6.4(6.4)$ & $97.4 \pm 5.6(5.7)$ \\
\hline
\end{tabular}

${ }^{\mathrm{a}}$ accuracy (mean $\% \pm$ S.D., $n=5$ ); ${ }^{\mathrm{b}}$ relative standard deviation $(\%)$. 

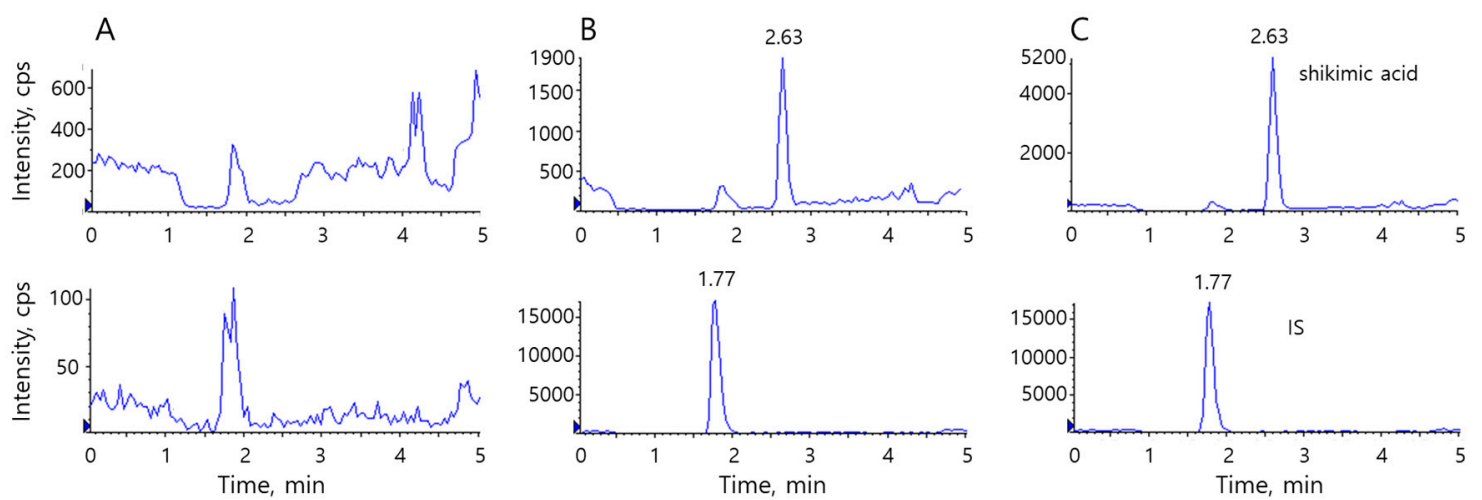

Figure 2. Typical chromatograms of shikimic acid (top) and diclofenac (internal standard (IS), bottom). (A) double blank, (B) spiked plasma with $10 \mathrm{ng} / \mathrm{mL}$ of shikimic acid, (C) a real sample, calculated to be $23 \mathrm{ng} / \mathrm{mL}$.

The extraction recovery was $84 \pm 5 \%$, and any matrix effect caused by endogenous plasma materials was negligible $(92 \pm 9 \%)$. Our assay reliably determined the shikimic acid concentration in rat plasma. Shikimic acid was stable in plasma under the tested conditions (Table 2). Although some instability was evident after long-term storage, it was within the acceptable range.

Table 2. Stability of shikimic acid in rat plasma under various conditions.

\begin{tabular}{ccc}
\hline Conditions for Stability Test & $\mathbf{1 0 0} \mathbf{~ n g} / \mathbf{m L}$ & $\mathbf{1 0 0 0} \mathbf{~ n g} / \mathbf{m L}$ \\
\hline room temperature for $4 \mathrm{~h}$ & $95.6 \pm 4.5^{\mathrm{a}}$ & $99.5 \pm 5.2$ \\
3-cycle freeze-thaw & $106.5 \pm 7.6$ & $98.6 \pm 6.2$ \\
post-extraction at $4{ }^{\circ} \mathrm{C}$ for $24 \mathrm{~h}$ & $98.5 \pm 5.4$ & $95.3 \pm 5.3$ \\
$-70{ }^{\circ} \mathrm{C}$ for 3 weeks & $110.5 \pm 9.2$ & $108.2 \pm 8.3$ \\
\hline a accuracy in plasma under various conditions (mean \% \pm S.D., $n=3$ ).
\end{tabular}

\subsection{Time Courses of Plasma Shikimic Acid Concentrations Following Iv and Ig Administration}

The mean time courses of plasma shikimic acid concentrations after iv and ig administration are shown in Figures 3 and 4, respectively. The pharmacokinetic parameters are listed in Table 3.

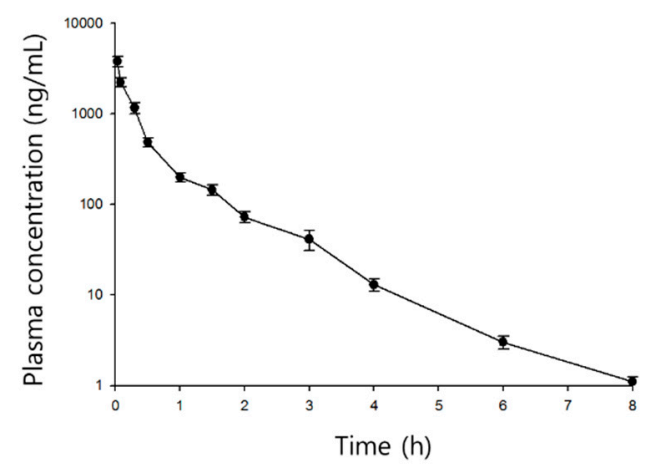

Figure 3. Time course of plasma shikimic acid concentrations following intravenous ( $2 \mathrm{mg} / \mathrm{kg})$ administrations in rats (mean \pm S.D., $n=5$ ).

Shikimic acid exhibited bi-exponential decay after iv administration, with a fast distribution $\left(5.57 \mathrm{~h}^{-1}\right)$ up to $1 \mathrm{~h}$ followed by slow elimination $\left(0.78 \mathrm{~h}^{-1}\right)$. The mean initial and steady state distribution volumes were 0.51 and $5.17 \mathrm{~L} / \mathrm{kg}$, respectively. The mean clearance was $1.79 \mathrm{~L} / \mathrm{h} / \mathrm{kg}$. After ig administration, the plasma shikimic acid level peaked at $904 \pm 48 \mathrm{ng} / \mathrm{mL}$ after about $3 \mathrm{~h}$ $(2.7 \pm 1.5 \mathrm{~h})$ and then declined mono-exponentially (half-life $=1.3 \pm 0.2 \mathrm{~h})$. Absorption seems to be 
relatively slow, given the mean $\mathrm{T}_{\max }$. However, as shown in the inset of Figure 4, three of five rats exhibited rapid absorption; the first peak appeared within $1 \mathrm{~h}$ and the second peak tended to be higher than the first.

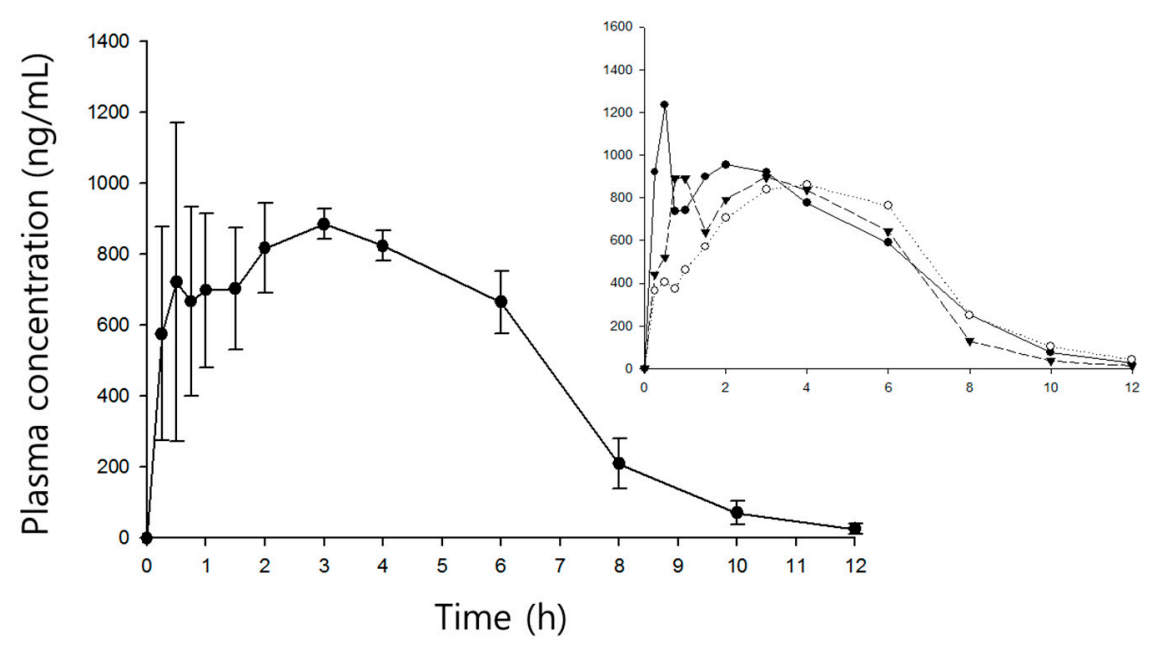

Figure 4. Time course of plasma shikimic acid concentrations following ig (100 mg/kg) administrations in rats (mean \pm S.D., $n=5$ ). Insert depicts three individual profiles significantly representing double peak phenomena.

Table 3. Pharmacokinetic parameter of shikimic acid after ig $(100 \mathrm{mg} / \mathrm{kg})$ and iv $(2 \mathrm{mg} / \mathrm{kg})$ administrations in rats (mean \pm S.D., $n=5$ ).

\begin{tabular}{|c|c|c|}
\hline Parameter & Intra-Gastric $(100 \mathrm{mg} / \mathrm{kg})$ & Intravenous ( $2 \mathrm{mg} / \mathrm{kg})$ \\
\hline $\mathrm{C}_{\max }(\mathrm{ng} / \mathrm{mL})$ & $904 \pm 48$ & - \\
\hline $\mathrm{T}_{\max }(\mathrm{h})$ & $2.7 \pm 1.5$ & - \\
\hline $\mathrm{t}_{1 / 2}(\mathrm{~h})$ & $1.26 \pm 0.20$ & $1.12 \pm 0.15$ \\
\hline $\mathrm{AUC}_{\mathrm{t}}(\mathrm{mg} \cdot \mathrm{h} / \mathrm{L})$ & $5.76 \pm 0.32$ & $1.12 \pm 0.06$ \\
\hline $\mathrm{AUC}_{\text {inf }}(\mathrm{mg} \cdot \mathrm{h} / \mathrm{L})$ & $5.81 \pm 0.32$ & $1.13 \pm 0.06$ \\
\hline $\mathrm{Cl}(\mathrm{L} / \mathrm{h} / \mathrm{kg})$ & $1.73 \pm 0.10$ & $1.79 \pm 0.09$ \\
\hline $\mathrm{Vi}(\mathrm{L} / \mathrm{kg})$ & - & $0.51 \pm 0.06$ \\
\hline Vss (L/kg) & - & $5.17 \pm 0.67$ \\
\hline $\mathrm{A}(\mathrm{ng} / \mathrm{mL})$ & - & $3500 \pm 385$ \\
\hline$\alpha\left(h^{-1}\right)$ & - & $5.57 \pm 0.61$ \\
\hline $\mathrm{B}(\mathrm{ng} / \mathrm{mL})$ & - & $387 \pm 50$ \\
\hline$\beta\left(\mathrm{h}^{-1}\right)$ & - & $0.78 \pm 0.10$ \\
\hline jioavailability, F (\%) & 10.4 & - \\
\hline
\end{tabular}

As shown in Figure 4, the interindividual variation during absorption was much greater than in the other phases, attributable to a significant double peak phenomenon (perhaps reflecting enterohepatic circulation and/or belated absorption by different regions of the gastrointestinal tract). In contrast to the terminal phase after iv administration, we did not observe bi-exponential decay, not only because the distribution was relatively short (and its phase thus insignificant), but also because absorption persisted for up to $3 \mathrm{~h}$. The $\mathrm{AUC}_{\mathrm{inf}}$ was over $99 \%$ of the $\mathrm{AUC}_{\mathrm{t}}$, indicating that the course of plasma sampling was sufficiently long to reveal the full time course of the plasma shikimic acid concentration. The total clearance of $1.73 \pm 0.1 \mathrm{~L} / \mathrm{h} / \mathrm{kg}$ was similar to that after iv administration. The absolute oral bioavailability of shikimic acid was about $10 \%$.

A couple of reports on the pharmacological action of shikimic acid in vivo have appeared $[14,24,25]$. Shikimic acid was administered orally to rats with streptozotocin-induced diabetes at 50 and $100 \mathrm{mg} / \mathrm{kg}$ [14], and 30 and $50 \mathrm{mg} / \mathrm{kg}$ [24]. It showed a promising anti-diabetic action comparable to those of metformin and glipizide and prevented retinopathy by exerting an antioxidant effect. 
At 25 and $50 \mathrm{mg} / \mathrm{kg}$, shikimic acid also reduced the severity of cerebral ischemic injury induced by arterial thrombosis [25]. As the extent of systemic exposure to shikimic acid remained unclear, we evaluated a pharmacological dose $(100 \mathrm{mg} / \mathrm{kg})$ to elucidate the relationship between systemic exposure and pharmacodynamics.

\section{Conclusions}

We devised a new bioanalytical method for determining the shikimic acid level in rat plasma using LC-MS/MS and conducted a pharmacokinetic study involving both iv and ig administration. The absolute bioavailability was about $10 \%$. Our findings will facilitate further work on the relationship between the pharmacokinetics and pharmacodynamics of shikimic acid.

Author Contributions: Conceptualization, B.S.S. and W.K.; methodology, K.N.; investigation, K.N. and H.-M.B.; writing-original draft preparation, B.S.S. and W.K. All authors have read and agreed to the published version of the manuscript.

Funding: This work was supported by the National Research Foundation of Korea (NRF) grant funded by the Korea government (MSIP) (No. 2015R1A5A1008958).

Conflicts of Interest: The authors declare no conflict of interest.

\section{References}

1. Bochkov, D.V.; Sysolyatin, S.V.; Kalashnikov, A.I.; Surmacheva, I.A. Shikimic acid: Review of its analytical, isolation, and purification techniques from plant and microbial sources. J. Chem. Biol. 2012, 5, 5-17. [CrossRef]

2. Rawat, G.; Tripathi, P.; Saxena, R.K. Expanding horizons of shikimic acid. Appl. Microbiol. Biotechnol. 2013, 97, 4277-4287. [CrossRef] [PubMed]

3. Barcellos, G.B.; Caceres, R.A.; de Azevedo, W.F., Jr. Structural studies of shikimate dehydrogenase from Bacillus anthracis complexed with cofactor NADP. J. Mol. Model. 2009, 15, 147-155. [CrossRef]

4. Rabelo, T.K.; Guimarães, A.G.; Oliveira, M.A.; Gasparotto, J.; Serafini, M.R.; de Souza Araújo, A.A.; Quintans-Júnior, L.J.; Moreira, J.C.F.; Gelain, D.P. Shikimic acid inhibits LPS-induced cellular pro-inflammatory cytokines and attenuates mechanical hyperalgesia in mice. Int. Immunopharmacol. 2016, 39, 97-105. [CrossRef]

5. Lu, F.; Yin, D.; Pu, Y.; Liu, W.; Li, Z.; Shao, Q.; He, C.; Cao, L. Shikimic Acid Promotes Oligodendrocyte Precursor Cell Differentiation and Accelerates Remyelination in Mice. Neurosci. Bull. 2019, 35, 434-446. [CrossRef]

6. Choi, M.; Choi, S.J.; Jang, S.; Choi, H.I.; Kang, B.M.; Hwang, S.T.; Kwon, O. Shikimic acid, a mannose bioisostere, promotes hair growth with the induction of anagen hair cycle. Sci. Rep. 2019, 9, 17008. [CrossRef] [PubMed]

7. Wang, M.; Wang, Y.; Omari-Siaw, E.; Wang, S.; Zhu, Y.; Xu, X. Reduced Burst Release and Enhanced Oral Bioavailability in Shikimic Acid-Loaded Polylactic Acid Submicron Particles by Coaxial Electrospray. J. Pharm. Sci. 2016, 105, 2427-2436. [CrossRef]

8. Adamson, R.H.; Bridges, J.W.; Evans, M.E.; Willams, R.T. Specoes differences in the aromatization of quinic acid in vivo and the role of gut bacteria. Biochem. J. 1970, 116, 437-733. [CrossRef]

9. Brewster, D.; Hones, R.S.; Parke, D.V. The metabolism of shikimate in the rat. Biochem. J. 1978, 170, $257-264$. [CrossRef]

10. Jensen, H.D.; Krogfelt, K.A.; Cornett, C.; Hansen, S.H.; Christensen, S.B. Hydrophilic carboxylic acids and iridoid glycosides in the juice of American and European cranberries (Vaccinium macrocarpon and V. oxycoccos), lingonberries (V. vitis-idaea), and blueberries (V. myrtillus). J. Agric. Food Chem. 2002, 50, 6871-6874. [CrossRef] [PubMed]

11. Malalgoda, M.; Meinhardt, S.W.; Simsek, S. Detection and quantitation of immunogenic epitopes related to celiac disease in historical and modern hard red spring wheat cultivars. Food Chem. 2018, 264, 101-107. [CrossRef] [PubMed] 
12. Scalabrin, E.; Radaelli, M.; Capodaglio, G. Simultaneous determination of shikimic acid, salicylic acid and jasmonic acid in wild and transgenic Nicotiana langsdorffii plants exposed to abiotic stresses. Plant Physiol. Biochem. 2016, 103, 53-60. [CrossRef] [PubMed]

13. Phillips, M.M.; Case, R.J.; Rimmer, C.A.; Sander, L.C.; Sharpless, K.E.; Wise, S.A.; Yen, J.H. Determination of organic acids in Vaccinium berry standard reference materials. Anal. Bioanal. Chem. 2010, 398, 425-434. [CrossRef] [PubMed]

14. Al-Malki, A.I. Shikimic acid from Artemisia absinthium inhibits protein glycation in diabetic rats. Int. J. Biol. Macromol. 2019, 122, 1212-1216. [CrossRef] [PubMed]

15. Zhang, Q.F.; Guo, Y.X.; Zheng, G.; Wang, W.J. Chemical constituents comparison between Rhizoma Smilacis Glabrae and Rhizoma Smilacis Chinae by HPLC-DAD-MS/MS. Nat. Prod. Res. 2013, 27, 277-281. [CrossRef] [PubMed]

16. US Department of Health and Human Sevices. Guideline for Industry: Bioanalytical Method Validation; Food and Drug Administration: Bethesda, MD, USA, 2001.

17. The Merck Publishing Group. The Merck Index, 14th ed.; The Merck Publishing Group: Darmstadt, Germany, 2006.

18. Kang, W. Simple and sensitive determination of nisoldipine in plasma using liquid chromatography-tandem mass spectrometry. Anal. Sci. 2006, 22, 1597-1599. [CrossRef]

19. Yamamoto, S.; Hayasaka, F.; Deguchi, K.; Okudera, T.; Furusawa, T.; Sakai, Y. Absorption and plasma kinetics of collagen tripeptide after peroral or intraperitoneal administration in rats. Biosci. Biotechnol. Biochem. 2015, 79, 2026-2033. [CrossRef]

20. Choi, S.; Kim, M.; Kim, C.; Hwang, J.K.; Kang, W. Quantitative determination of xanthorrhizol in rat plasma by HPLC-MS/MS and its application to a pharmacokinetic study. J. Pharm. Biomed. Anal. 2017, 132, 56-59. [CrossRef]

21. Son, H.; Noh, K.; Kang, C.; Na, M.; Oh, S.; Song, I.S.; Kang, W. HPLC-MS/MS analysis of ilimaquinone and its application in a pharmacokinetic study in rats. J. Pharm. Biomed. Anal. 2019, 166, 291-294. [CrossRef]

22. Son, H.; Kang, W. Quantitative determination of bilobetin in rat plasma by HPLC-MS/MS and its application to a pharmacokinetic study. Biomed. Chromatogr. 2020, 34, e4784. [CrossRef]

23. Zamir, L.O.; Luthe, C. chemistry of shikimic acid derivatives. Synthesis of specifically labeled shikimic acid at C-3 or C-4' . Can. J. Chem. 1984, 62, 1169-1175. [CrossRef]

24. Orhan, N.; Aslan, M.; Pekcan, M.; Orhan, D.D.; Bedir, E.; Ergun, F. Identification of hypoglycaemic compounds from berries of Juniperus oxycedrus subsp. oxycedrus through bioactivity guided isolation technique. J. Ethnopharmacol. 2012, 139, 110-118. [CrossRef] [PubMed]

25. Ma, Y.; Xu, Q.P.; Sun, J.N.; Bai, L.M.; Guo, Y.J.; Niu, J.Z. Antagonistic effects of shikimic acid against focal cerebral ischemia injury in rats subjected to middle cerebral artery thrombosis. Acta Pharmacol. Sin. 1999, 20, 701-704.

(C) 2020 by the authors. Licensee MDPI, Basel, Switzerland. This article is an open access article distributed under the terms and conditions of the Creative Commons Attribution (CC BY) license (http://creativecommons.org/licenses/by/4.0/). 